\title{
From Zone and Subjects to Line and Territory: A Theoretical Reflection on the Mexican-Guatemalan Boundary Dispute (1821-1882)
}

Soili Buska

\section{Introduction}

This essay will examine the process of boundary dispute and definition between Guatemala and Mexico after 1821. The disagreement and negotiations over limits between countries revealed the wide-reached interest in delineation of national territories, fundamental for the formation of independent nation-states. Several ideological and economic factors affected the dispute and the final boundary treaty between Guatemala and Mexico. An important ideological influence played the nineteenth-century romantic nationalism, which made the Creole elites to establish particular and unique national entities. Moreover, the worldwide drive to map the earth's surface by using tools of the modern cartographic science played an important role in the process of MexicanGuatemalan boundary definition. The postcolonial expansion of agro-export economy in Central America, and especially the coffee boom starting in the Mexican southeastern and Guatemalan western borderlands from the second half of the nineteenth century onward became an economic stimulus for boundary definition process. This is the historical context, in which Mexican and Guatemalan elites were engaged in a longrunning debate and negotiations over the common border. 
In this essay I will explore the ideological aspects rather than the economic factors of the course of boundary creation. I will discuss the Mexican and Guatemalan elites' changing concepts of boundaries and sovereignty, and the ways in which these transformations in ideas and perceptions affected the final boundary treaty between the two countries. This theoretical incursion into the Guatemalan-Mexican boundary formation process has been inspired by two innovative studies on border histories, the works of Peter Sahlins and Thongchai Winichakul, on national boundary definition processes in Europe and Asia, respectively. Basing on these seminal works I argue that during the approximately seven decades of dispute and negotiations, Guatemalan and Mexican political elites and intellectuals debated over boundaries in changing terms reflecting their changing conceptions of sovereignty. Initially, they disputed the ownership of a province, using the mental map of Spanish colonial organization composed of regional and local jurisdictions over subjects without clearly defined territories. They combined this mental map with liberal ideas of people's will and town citizens' sovereignty. However, the final boundary treaty was written in terms of modern geography and cartography concerned with the exactitude of the borderline as a limit of the nation, what reveals a transition from colonial type of space perceptions to modern concepts of territorial sovereignty. This modern geographical understanding led the political elites-seeking to define their nation's (geo)body - to pursue an exact definition of national territory based on continuous (frequently straight) lines instead of some loose boundary markers used earlier.

I have organized this essay in the following way: I will first briefly summarize some ideas on pre-modern and modern geographical thinking and discuss the contributions of Peter Sahlins and Thongchai Winichakul in order to introduce the conceptual framework of my reflections. Then, I will provide a short account of the historical process which turned Chiapas into a bone of contention between Mexico and Guatemala. And, finally, I will examine the development of the boundary negotiations between the two countries. Due to the character of my sources, I will focus on the elite and intellectual perspectives and discourses on the boundary dispute and the final agreement. The subaltern views of territories and boundaries remain for a future investigation. Geographically, my study 
focuses on the border area on the Western Guatemala bordering with the present-day state of Chiapas.

\section{Pre-Modern and Modern Geographical Thoughts and Map Consciousness}

Historical geographers have stated that ancient cartography lacked modern map consciousness, and that "mapping as we know it began, long after the fall of Rome, as a response to the demands of the modern nation-state." Gavin Sundwall has analyzed the way in which Roman Empire's geographer Ammianus Geographicus, instead of drawing a visual map, worked out a "verbal map" of the places he visited. ${ }^{2}$ According to Sundwall, "the ancients saw their world very differently from the vision of modern geography. Their purposes in writing geography were different as well." ${ }^{3}$ This assessment suggests that geographical conceptions follow not only the scientific or technical developments but also the political purposes of mapping spaces and territories.

The invention of instruments such as the quadrant and the pendulum clock enhanced the development of modern European geography from sixteenth and seventeenth centuries onward. ${ }^{4}$ The nineteenth-century nationalists applied this knowledge to creating nations as particular and unique entities with exactly drawn contours. The idea of territorial sovereignty as precondition of a national state inspired the mapping of the globe's surface and the assigning of clearly defined territories -or bodies- for each nation.

Therefore, mapping is not a simple question of implementing advances in geography and cartography but a result of the dialectic relationship between political purposes and scientific developments. ${ }^{5}$

\footnotetext{
${ }^{1}$ Gavin A. Sundwall, "Ammianus Geographicus", American Journal of Philology 117(4): 620, 1996.

${ }^{2}$ Ibid., p. 639, 641.

${ }^{3}$ Ibid., p. 620-621.

${ }^{4}$ Gregory H. Nobles, "Straight Lines and Stability: Mapping the Political Order of the AngloAmerican Frontier", The Journal of American History 80(1): 13, June 1993.

${ }^{5}$ An important discussion on the role of geopolitics in modern cartography and Western world vision can be found in: Carlos Granados, "La visión mercatoriana del mundo y las cambiantes
} 
According to Peter Sahlins, the ancient idea of boundaries did not carry a political connotation. A linear boundary as a separating line between two different political entities was something new in early nineteenth century Europe. The idea of a separating line was a result of differentiation that took place in the concpets of boundary and frontier in the late thirteenth-century. Frontier acquired its significance as a zone facing the enemy, or the unknown, while boundary meant a limit or a border. From the sixteenth century onward, Europeans started talking about the 'boundaries of the frontier' ${ }^{6}$ But in Europe, and especially in France, the Old Regime was still conceived not as a territorial sovereignty but as a jurisdiction over subjects.

Sahlins has argued that the French Revolution added a national content to the idea of territorial sovereignty, which led to a vigorous politicization of territory in the nineteenth century Europe. ${ }^{7}$ While the French Revolution's role in politicizing territory can be discussed, Sahlins's attention to the transformation of ideas and concepts during one historical process represents an indisputable contribution for boundary studies. In French and Spanish Cerdanya, Sahlins finds that the official concepts of territory varied during the border definition process. For Sahlins, when (before the nineteenth century) diplomats and commissioners spoke about "the 'delineation' and 'demarcation' of the frontier, they did not think in terms of the modern notion of a linear boundary separating distinct national territories. Instead, they posed the problem in jurisdictional terms." But in 1830, after two hundred years of negotiations and treaties on boundaries, the officials involved in the boundary business recognized the need to "define the true line of division of the two kingdoms". ${ }^{9}$ According to Sahlins, this idea of boundary as an exact and straight line introduced the question of territorial violations into nineteenth century

relaciones de poder global", in Revista Estudios, Universidad de Costa Rica (12-13): 181-192, 1995-1996.

${ }^{6}$ Peter Sahlins, Boundaries: The Making of France and Spain in the Pyrenees (Berkeley - Los Angeles - London: University of California Press, 1989), 6.

7 Ibid., p. 4.

${ }^{8}$ Peter Sahlins, "The Nation in the Village: State-Building and Communal Struggles in the Catalan Borderland during the Eighteenth and Nineteenth Centuries", Journal of Modern History 60 (June 1988): 238-9.

${ }^{9}$ Sahlins, Boundaries, 239. 
high diplomacy. ${ }^{10}$ This statement also is true for the case of the boundary process between Guatemala and Mexico, discussed in this paper.

In the same sense in East Asia, Thongchai Winichakul has shown how the pressures exerted by a European power forced the Siamese kingdom to agree negotiate boundaries in terms of modern European geography. For the first half of the nineteenth century, the Siamese government considered boundaries to be a local issue -and in no sense a national problem. It could not figure out the relevance of boundary delimitation in the form of an exact continuous line drawn from the perspective of the nation's administrative center. ${ }^{11}$ After several decades of disencounters between two different concepts of territory and boundaries -between two different geographical understandings- the Siamese court finally "conceded to speak of the matter in the way that the British preferred" in the late nineteenth century. ${ }^{12}$ While formerly the limits of Siamese kingdom could have been defined only by the allegiance of local powers to the center, now the Siamese elite was concerned with territory, with the fixing of a "geobody" of Siam and sovereignty over that body. ${ }^{13}$ So, in Siam the image of sovereignty shifted "from traditional rituals and practices of submission to a new representation which dealt directly with horizontal planes." 14 The idea of sovereignty over people gave way to the idea of sovereignty over geographically defined territories.

Twentieth-century geographers have made the distinction between the European concepts of boundaries in pre-modern and modern times. ${ }^{15}$ Peter Sahlins has shown how these boundary conceptions have changed not simply following a progressive and linear

${ }^{10}$ Ibid., 243

${ }^{11}$ Thongchai Winichakul, Siam Mapped: A History of the Geo-Body of a Nation (Honolulu: University of Hawai'i Press, 1994), p. 64.

12 Ibid., 67.

${ }^{13}$ Winichakul uses the term geo-body to refer to the idea of the nation as a body that needs to be defined and delimited. Consequently, nation is considered to have its body before any mapping is done. And, when the state is not successful in its attempts to control nation's body, it is interpreted in terms of loss. Ibid., pp. 16-17.

${ }^{14}$ Ibid., 112.

15 The geographer of U.S. Department of State S.Whittemore Boggs stated in 1940 that, "The functioning of international boundaries throughout the world today is largely the outgrowth of nationalism as it developed in Europe, especially within the last two decades. The earliest boundaries were not lines but zones or border marches." S. Whittemore Boggs. International Boundaries: A Study of Boundary Functions and Problems (New York: Columbia University Press, 1940). 
development based on scientific advancements, but rather corresponding to the purposes of the organization of political power and control by modern states. For France and Spain, Sahlins states that "The history of the boundary between 1659 and 1868, then, can hardly be summarized as the simple evolution from an empty zone to a precise line, but rather as the complex interplay of two notions of boundary-zonal and linear-and two ideas of sovereignty -jurisdictional and territorial."16 This kind of interplay between different notions of boundary and sovereignty can be detected also in postcolonial Mexico and Guatemala.

In colonial New Spain and Kingdom of Guatemala, territorialities were based on a combination of Castilian and Mesoamerican traditions of administrative organization. During the Aztec regime Mesoamerica was composed by regions with broad autonomy and without clearly defined territorial limits. The Spanish conquistadors saw America with eyes of Castilian citizen and town councilman, imposing their mental landscape of towns and municipal territories on the world they encountered. They also applied their experience of 'reconquest' of Spain, where each territory conquered was called a kingdom, even though they lacked territorial governments. ${ }^{17}$ Thus, the Spaniards brought with them the municipal organization of Castile and adapted it to indigenous administrative traditions. ${ }^{18}$ In both Mesoamerican and Spanish traditions the frontiers did not have clear limits and sovereignty meant jurisdiction over people in a certain town or village rather than over territories. After the conquest, the Crown was soon in trouble due to conquistadors' broad autonomy in America. Trying to mitigate the loss of control, the Crown established corregimientos, which converted the conquistador-encomendero into a royal official. Later the introduction of vice regal authority in 1535 was meant to fortify monarch's authority over local colonial authorities. ${ }^{19}$ The colonial spatial

\footnotetext{
${ }^{16}$ Sahlins, Boundaries, p. 7.

17 Helen Nader, Liberty in Absolutist Spain: The Habsburg Sale of Towns, 1516-1700

(Baltimore and London: The John Hopkins University Press, 1990), pp. 42, 72.

${ }^{18}$ See Nader, p. 41, 42, 72, 86; and James Lockhart, The Nahuas After the Conquest: A Social and Cultural History of the Indians of Central Mexico, Sixteenth Through Eighteenth Centuries (Stanford, California: Stanford University Press, 1992), pp. 14-58.

${ }^{19}$ Colin M. MacLachlan, Criminal Justice in Eighteenth Century Mexico: A Study of the Tribunal of the Acordada (Berkeley - Los Angeles - London: University of California Press, 1974), p. 17-18.
} 
organization was based on the idea of controlling rather people than clearly defined territories.

In the late colonial period, the Bourbon reforms served to put Spain's colonial possessions under a more direct Crown control. The measures taken by the monarchy led the local elites to try to occupy the new political positions as local authorities. Marcello Carmagnani has posed that the elite's renewed interest in cabildos, local military, commercial representations, and other institutions consolidated local and regional territorial identities and sense of belonging to certain "patria". According to Carmagnani, Bourbon reforms actually institutionalized the informal territorialities by means of ayuntamiento, a territorial community integrated by a social settlement pueblo-, which controlled a certain area. ${ }^{20}$ Carmagnani's position leads us to guess if the Bourbon intendency system helped to form a base for a slow change in local elites' perceptions of spatial organization and sovereigny. However, and even if this transformation is possible, it did not affect the practices of spatial organization and border definition immediately after independence in Mexico and Central America. The colonial mental maps survived the loss of the regime and affected Mexican and Central American political cultures and state organization long after the fall of Spanish colonial regime.

\section{Independence and Annexation of Chiapas}

Chiapas has been a frontier region for Mesoamerican centralized societies since ancient times. At the moment of the Spaniards' arrival in Mexico, the Aztec Empire collected tributes in Soconusco and some towns in Chiapas such as Comitán and Zinacantan. For the most of the colonial period Chiapas formed part of Kingdom of Guatemala.

\footnotetext{
${ }^{20}$ Marcello Carmagnani defines territoriality in following terms: "La territorialidad se distingue así de la simple división administrativa por la capacidad de desarrollar históricamente un conjunto de funciones que van configurando una tradición, la de una común pertenencia a un territorio y de un sentimiento de una comunidad de intereses sobre el territorio." See, Marcello Carmagnani, "Territorios, provincias y estados: las transformaciones de los espacios políticos en México, 1750-1850", in: Josefina Zoraida Vázquez, et al, La fundación del estado mexicano (México: Editorial Patria, 1994), p. 52.
} 
Chiapas reached independence from Spain with about 130,000 inhabitants, most of them Indians. According to the 1814 census there were 105,352 Indians, 21,477 mestizos, and 3409 Spaniards. ${ }^{21}$ The principal cities were Ciudad Real and Comitán, and there were also three important towns, Tuxtla, Tonala, and Palenque; as well as 157 villages. ${ }^{22}$ In the late eighteenth century the number of Spanish and mestizo settlers quickly increased. Farmers and ranchers, who had come to Chiapas for land, labor, and political power, primarily made up this non-Indian population. The internal rivalries among these elite groups marked the process of Chiapas's independence from Guatemala and its final attachment to Mexico. ${ }^{23}$ After independence the wealthy landowning families expanded and progressively deprived Indian communities of their lands. ${ }^{24}$ To defend their class interests the elites participated enthusiastically in the process of defining Chiapas's postcolonial political affiliation. Other constituents of the group in power were clergy, government officials, merchants, and the military. Those who supported joining Mexico expected more autonomy after ending colonial Guatemala City’s control. ${ }^{25}$

With the membership of almost all the previous provinces of the Kingdom of Guatemala, Mexico was expected to become a powerful empire. However, when the emperor Agustin Iturbide fell in October 1823, and Mexico took a republican path, the Central American provinces -including Chiapas- decided to separate from the ex-empire. With the exception of the pro-Mexican Ciudad Real, Chiapanecan towns and villages supported the "Plan de Chiapa Libre" in order to make Chiapas independent from

\footnotetext{
${ }^{21}$ See, Antonio García de León, Resistencia y utopía: memorial de agravios y crónica de revueltas y profecías acaecidas en la provincia de Chiapas durante los últimos quinientos años de su historia, tomo 1 (México: Ediciones Era, 1985), p. 140. According to Boletín del Archivo General de Chiapas, IV (6): 15, enero-junio 1956, the numbers are 105,252; 21,507 and 3539 , respectively. The slight difference is probably due to errors in adding up the numbers of inhabitants of different villages.

22 Thomas Benjamin, A Rich Land, A Poor People: Politics and Society in Modern Chiapas (Albuquerque: University of New Mexico Press, 1989), p. 5.

${ }^{23}$ Benjamin, p. 6.

24 Jan de Vos, Vivir en frontera: la experiencia de los indios de Chiapas (México: CIESAS, 1994), pp. 160-166.

${ }^{25}$ García, p. 145.
} 
Mexico. $^{26}$ In July 1824, the cabildo of Soconuscan Tapachula went as far as to separate from Chiapas and to join the Central American Federation. ${ }^{27}$

This new situation turned out to be even briefer than the experiment of Mexican Empire. In two months a plebiscite was organized to decide with which national state Chiapas (including Soconusco) would remain. This episode has been debated back and forth among Mexican and Central American patriotic intellectuals since those days, and it became an especially hot topic during the boundary process. Depending on an author's sympathies the plebiscite was used as proof of Mexico's sovereignty over Chiapas, or else its illegitimacy. ${ }^{28}$ In the election 96,829 voted for joining Mexico, 60,400 favored Republic of Guatemala, and 15,724 abstained. ${ }^{29}$ Contemporary writers have paid attention to the relation between the number of voters and number of inhabitants, arguing that Chiapas's population could not have increased that much (from 130,000 to almost $173,000)$ since 1814 when the last census was done. Some authors have ironically stated that Chiapas was the first case in world history, in which women -and even babies-

${ }^{26}$ See García, 146,, and Benjamin, xv.; Vos, Las fronteras de la frontera sur, p. 91, and Sentimiento chiapaneco, p. 25, and Arnoldo Hernández Merida y María del Rosario Velázquez Gumeta, Chipas: Síntesis histórica. País de los mayas, tierra del mestizo (Chiapas, México: 1984), pp. 83-91.

27 See, "Acta por la cual los representantes de los ayuntamientos del partido de Soconusco deciden ser parte de las Provincias Unidas del Centro de América, separándose de Chiapa", in: Vos, Las fronteras de la frontera sur, pp. 146-148.

${ }^{28}$ For instance, the Mexican Foreign Minister J.M.Lafragua wrote in 1875: "Queda por tanto demostrado: que no solo no hubo ilegalidad en la declaración de 12 de Setiembre de 1824, sino que esta fué tan explícita y tan libre, que no deja sombra alguna acerca de la voluntad de Chiapas. Estos hechos, que constan en documentos oficiales, fundan de la manera mas sólida el derecho de México á la Provincia de Chiapas y cierran la puerta á toda discusión, porque ninguna es posible en vista de la espontaneidad y de la firmeza con que se verificó la incorporación." México - Secretaría de relaciones exteriores, Cuestión de límites entre México y Guatemala. Nota y memorandum que dirigió el Señor Ministro de Guatemala al Gobierno de México y contestación dada por el Ministro de Relaciones Exteriores de la República (México: Imprenta del Gobierno, en Palacio, á cargo de J.M.Sandoval, 1875), p. 18. See also, Manuel Larráinzar, Chiapas y Soconusco: la cuestión de límites entre México y Guatemala (Chiapas, México: Gobierno del Estado de Chiapas / Consejo National para la cultura y las artes, 1996; and César Sepúlveda, p. 147. Guatemalan Andres Dardon has expressed an opposite view: "de 170.000 almas que componían la Provincia, apenas se podía considerar á 10.000 con la facultad de pensar en este asunto. Que había partidos enteros de pura gente infeliz, incapaz de conocer lo que les tuviera más cuenta, é ignorantes hasta lo sumo: que de éstos se habían valido los intrigantes para hacer sus actas al antojo; (...) que los representantes no tenían liberatad á causa del lugar en que se encontraban y hallándose en presencia del representante de México." In, Dardon, Memoria sobre la cuestión de límites entre Guatemala y México, presentada al señor Ministro de Relaciones Exteriores por el jefe de la Comisión Guatemalteca. 1900. Reprinted in Guatemala: Centro Editorial "José de Pineda Ibarra", Ministerio de Educación Pública, 1964. 
voted. ${ }^{30}$ Unfortunately, there have been no serious efforts to examine the way voting was actually carried out, which is an important issue taking into account that there were no unified electoral procedures in the early independent Mexico or Central America. ${ }^{31}$

Chiapas was incorporated to Mexico by the plebiscite. The case of Soconusco was more complicated because, even though its powerful oligarchic families were pro-Mexican ${ }^{32}$, an important part of Soconuscan elite desired to belong to Central American Federation. Due to this conflict the Mexican and Guatemalan governments allowed Soconusco stay neutral for almost eighteen years, until, in 1842, when the Oaxacan army following Santa Anna's orders occupied the province, and the General declared it part of Chiapas and Mexico. ${ }^{33}$ The military incorporation of Soconusco to Mexico was a bitter drink for the Guatemalan government who considered it a violation of the previous agreement. ${ }^{34}$ The consequence was a long-running dispute between Mexican and Guatemalan governments, focused first mainly on the possession of Chiapas and Soconusco, and later on the definition of the boundary between two national territories. During the decades of quarreling the leading groups' concepts of sovereignty and boundary suffered important transformations.

29 María Esther Pérez Salas and Diana Guillén, Chiapas: una historia compartida (M[exico: Instituto de Investigacionies Dr. José María Luis Mora, 1994), pp. 73-74.

30 Jan de Vos quotes Manuel Trens's (1957) commentary on this plebiscite: "Es curioso que estos señores representantes se hayan excedido en la aplicación de la forma plebiscitaria, pues ni entre la plebe romana ni entre los franceses de la Revolución, ni en los del Consulado, tuvieron voto las mujeres y los niños, las primeras por carecer de derechos políticos y los segundos por ser inconcientes, y en Chiapas, según los padrones de la Junta, votaron hasta los lactantes." Vos, El sentimiento chiapaneco: ensayo sobre la independencia de Chiapas y su agregación a México (México: Rodfigo Nuñez Editores,1991), p. 29-31. See also, Vos, Las fronteras de la frontera sur, pp. 93-94.

${ }^{31}$ Carmagnani, p. 68.

32 María de los Angeles Ortiz Hernández, "La oligarquía regional del Soconusco, Chiapas en el siglo XIX", Ponencia presentada en el Tercer Congreso Centroamericano de Historia, San José, Costa Rica, julio 1996, p. 3.

${ }^{33}$ See, "Decreto por el cual el presidente Antonio López de Santa-Anna declara agregado irremisiblemente a la República el territorio de Soconusco", México, 11 de septiembre de 1842, in: Vos, Las fronteras de la frontera sur, p. 152. On the Mexican position about the agreement and the invasion, see México. Secretaría de Relationes Exteriores. Cuestión de límites entre México y Guatemala. Nota y memorandum., pp. 36-45.

${ }^{34}$ See, William R. Manning, Diplomatic Correspondence of the United States. Inter-American Affairs, 1831-1860, Vol. III -Central America 1831-1850 (Washington: Garnegie Enfowment for International Peace, 1933), doc. 789, pp. 141-142 and doc. 827, pp. 212-216. Accroding to Aura Arriola, the incorporation of Soconusco to Mexico was motivated by the fear of alliance that could be formed between Central America and Yucatan. See, Aura Marina Arriola, Tapachula, "La perla del Soconusco", ciudad estratégica para la redefinición de las fronteras (Guatemala: FLACSO, 1995), pp. 19-20. However, there is no serious study of the links and the possible negotiations between Yucatecan and Central American political elites in that time. 


\section{Boundary Dispute and Agreement}

The independence process and the postcolonial state organization and formation resulted in a proliferation of ardent political pamphlets. Mexican and Guatemalan elites were embroiled in a hard-fought polemics over national and international politics. The debate on the possession of Chiapas and Soconusco continued, but at the same time the discourses began focusing on the marking out of a clear limit between Mexico and Guatemala. Guatemalans were more reluctant to adopt the new terms of discussion than Mexicans, probably because the Guatemalan elites cultivated hope for Chiapas's rejoining Central America, or Guatemala. In April 1824, a Guatemalan official paper stressed on Chiapanecans' right and convenience to stay with Central America, and at the same time, provided heavy reasons why Chiapas should be part of Guatemala rather than of Mexico:

"Chiapa, dividida de la nueva españa por una montaña que parece puesta por la naturaleza para separarla de esta república, dista de México cerca de 300 leguás [sic] al mismo tiempo que solo 120 la separan de esta capital.

No es creible que una voluntad ilustrada, libre en su pronunciamiento, y sin influencias que la coarte,prefiera tener en lugar tan remoto el centro de su administracion suprema, y sugetarse á las dilaciones y gastos que son precisos quando los recursos deben interponeres a tamaña distancia. Los pueblos aman siempre tener en su seno mismo el gobierno que debe regirlos; y cuando carecen de elementos necesarios para constituirse independientes, prefieren siempre su union con el mas vecino. ",35

For Guatemalans the primary criteria of a province's political affiliation was, on the one hand, the distance from the center, and, on the other, people's will based on their understanding of their best. The idea was that enlightened people would clearly realize the benefits of the central government's near location. Chiapanecans' own criteria for choosing their membership, however, seemed to go in the opposite direction.

Guatemalans also combined factors such as nature and colonial regime-which, by the way, was perceived at the same time as something natural and representative of reasonin order to demonstrate that belonging to Guatemala instead of Mexico would be natural 
and rational for Chiapas. Central American government's commissioner Pedro Molina declared in his Memoria addressed to Mexican plenipotenciario Manuel Diez de Bonilla in 1832:

"Dos grandes naciones limitan nuestro territorio, México y Colombia: Chiriqui al S.E. y al N.O.E. Chilillo, son nuestros términos naturales: un largo desierto media entre Costa Rica y Chiriqui; y entre Chiapas y Tehuantepec, las altísimas montañas de Chilillo, que a la manera de los Pirineos y los Alpes han debido separar en dos distintas naciones la población que se halla de esta y de aquella parte de los indicados montes. El Poder confirmó estos límites después, aislando en este centro con título de Reino, la Capitanía General de Guatemala. Nada tendríamos que contender con la una ni con la otra nación limitrofes, si ellas nos dejaran en pacífica posesión de nuestro territorio. ",36

Ten years later, in the protest against Soconusco's occupation by Santa Anna in 1842, the Guatemalan government acclaimed:

"Y en cuanto á límites naturales, ningunos son mas propios que los de las montañas del Chilillo, que han sido las divisorias de ambos reinos, y los cuales fijó el Gobierno español, sabio en acomodar los de estos paises á las circunstancias geográficas y cercania de los pueblos que componian las secciones del antiguo régimen." 37

For the purposes of postcolonial nation building in Guatemala, the Spanish colonial rule turned out to be wisely organized in 'accommodating countries' in a natural way following the geographical circumstances. A combination of nature and Spanish rule guaranteed the justice of Chiapas's belonging to Guatemala. For Guatemalans, "natural limits" served to separate Chiapas from Mexico. The topographical accidents between Chiapas and Western Guatemala did not count for dividing elements; at least, they were not perceived. In these documents, we can find the idea of boundary as division, as natural obstacle that separates people. However, it is not the exact line between two territories, notion that dominated the treaty of 1882.

${ }^{35}$ Gaceta del Gobierno Supremo de Guatemala, \#7, 4/26/1824, p. 47.

36 Andrés Clemente Vázquez, "Bosquejo histórico de la agregación a México de Chiapas y Soconusco y de las negociaciones sobre límites entabladas por México con Centro América y Guatemala", Boletín del Archivo Histórico Diplomático Mexicano 36: 189, 1932. From here onward this source will be abbreviated as AHDM.

37 Guatemala. Reclamación y protesta del Supremo Gobierno del Estado de Guatemala sobre la ocupacioón de Soconusco, por tropas de la República mexicana, con los documentos en que se fundan (Guatemala: Imprenta de la Paz, 1843), p. 4. 
One of the problems experienced by Mexican and Guatemalan governments on their common borderlands was that, during postcolonial power struggles, the political dissidents usually sheltered themselves in the frontier villages out of the reach of their respective governments. This fact casts serious doubt of the real authority of either state over their borderlands. The old order of autonomous municipal jurisdictions was still in force during the first decades after independence from Spain. Before Soconusco's occupation by Mexican troops, a delegate of Guatemalan President José Diego Lara wrote in 1840:

"A cada paso los criminales de este departamento se están yendo á refugiar á aquella provincia [Soconusco], sin que sea posible conseguir de autoridades que los entreguen á los tribunales, y aun á este gobierno que se los ha reclamado. Como el citado Soconusco se ha dividido en tres municipalidades que se gobiernan enteramente independientes, y lo que sucece frecuentemente se han hecho rivales unas de otras, basta que una tome una medida, para que la otra la contrarie; si Tapachula persigue á los delincuentes que se le pide, Tuxtla chico los ampara y protege, y cuando se dirige el gobierno ó algun tribunal á ellas reclamando la falta, se disculpan las unas con las otras. ${ }^{38}$

It is probable that the new states' desire of achieving real control over their borderlands motivated the Mexican-Guatemalan boundary definition process from the mid nineteenth century onwards. Both countries' military carried out incursions and occupations on the border area, where the command of these new national states was extremely weak.

While Guatemalans were still thinking mainly in old terms of boundary and sovereignty, Mexicans were accustoming themselves to modern concepts of boundaries in defining national territory. In 1830s, Mexican government sent Manuel Diez de Bonilla as 'Ministro Plenipotenciario y Enviado Extraordinario' to Central America and Colombia. His mission was to achieve treaties on friendship, commerce, navigation, and limits with these countries. According to the instructions given to Bonilla, he was first to pass by Chiapas acquiring "a complete knowledge on the questioned territories of Soconusco and of Petén." ${ }^{39}$ Chiapas's Governor was asked to have everything ready,

\footnotetext{
${ }^{38}$ Ibid., p. 14. Emphasis is mine.

39"...una instrucción completa de los territorios cuestionados de Soconusco y de la parte del Petén", AHDM, p. 5.
} 
"Para que tenga preparados todos los materiales necesarios para ventilar con acierto esta materia, en la cual debería atenderse no sólo al punto de derecho, sino también a la conveniencia de ambas Repúblicas, señalándose entre ellas en cuanto posible sea, límites naturales, fácilmente discernibles y que no interrumpan comunicaciones de hábito y costumbre entre dos poblaciones vecinas, ocurriendo en cuanto se pueda en tales casos a compensaciones ventajosas a ambas partes y a las inclinaciones de los pueblos en cuestion.", 40

The idea of a separating line is present in this plan to establish a boundary that would disturb as little as possible local people's everyday life and that would coincide as much as possible with the "natural" limits. The problem was that there really was no consensus of the location of those natural limits. Characterizing Soconusco's borderlands with Central America, a Chiapanecan official said:

"El río de Tilapa por la costa y el de Petacalapa por Quezaltenango, son los que se han conocido por la línea divisoria del Partido de Soconusco con la República del Centro. En cuando al Partido de Llanos varían algún tanto, pues algunos creen que es el paraje llamado Rincón Tinaja, otros el río Nenton y otros el de Santa Catarina; pero adoptando un término medio, parece justo y sin agravio de ambas naciones, fijar los límites en el expresado río Nenton. ${ }^{, 41}$

It was not always easy to find those natural and just points for drawing the line, but with the information acquired in Chiapas, Bonilla was supposed to prepare a proposal of a formal boundary treaty and present it to Guatemalan government. At this point, the terms of negotiations, the boundary conceptions of the two parts did not coincide.

Guatemalans still wanted to debate the question of affiliation of Chiapas and Soconusco, while Mexicans were eager to establish a limit of their national territory-including these departments. Yet, it also seems not to have been clear to Mexicans themselves, what kind of boundaries or treaty they were pursuing. For the Chiapanecan and Soconuscan elites it was likewise difficult to imagine the issue in terms of drawing a straight line for boundary. Initially the Mexican government's instructions to Bonilla included the idea that the boundary line be established respecting local peoples' properties and spaces. This, however, was an uncertain idea that was strongly supported neither by Mexicans nor by Guatemalans.

${ }^{40}$ Ibid., p. 5. 
The relationship between Guatemala and Mexico worsened in 1833, apparently due to the problems caused by the Guatemalan and Central American dissidents' political activities in Soconusco and Chiapas. ${ }^{42}$ The two countries began accusing each other of having plans to militarily occupy the disputed region. The episode of a Guatemalan visitor caught in Chiapas, for being -according to Mexican government- a spy, illustrates once more the survival of colonial territoriality and geographical thinking in the region. The alledged spy, Manuel José López, was told to have passed incógnito through the town of Comitán, "sin presentar su pasaporte para los debidos efectos a la autoridad respectiva de aquel punto",43 and "como López pasó por Comitán sin presentarse a la autoridad alguna, se concibieron en su viaje vehementes sospechas." ${ }^{44}$ Thus, everyone knew López was in town, but while he did not present himself voluntarily to the Alcalde, he was considered to be there clandestinely. His behavior was considered dishonest and mysterious, and it justified the accusations of spying. The idea behind seems to be that it is not the contact with the territory but with the people that defines were one is. One is not considered to have entered in a country or foreign territory before he/she has made contact with its inhabitants - or, as in this case, with its authorities.

Another episode illustrating the survival of the colonial space conceptions after independence is the visit of US writer John Stephens in Central America. When Mr. Stephens traveled from Central America to Yucatan in the late 1830s, there was no defined borderline between Guatemala and Mexico, and no one checked passports on the border. During his trip through Western Guatemala toward Mexican border, always when arriving to a town, Stephens presented his "passport" to the alcalde that gave the authorization to continue the journey, and some logistic support. On the possibility of getting permission to enter Mexico, Stephens wrote:

41 "Expediente instruído por la Legislatura de Chiapas sobre las cuestiones con Centro América", AHDM, p. 55.

42 Ibid., p. 254.

43 Ibid., p. 349.

${ }^{44}$ Ibid., p. 353. 
"In consequence of the throng of emigrants form Guatimala [sic] toward Mexico, no one was admitted into that territory without a passport from Ciudad Real, the capital of Chiapas, four or five days' journey from the frontier. "45

Thus, in the late 1830s, the traveler was supposed to enter into Mexico and travel four or five days in order to obtain permission to enter the country in the first place. There was a certain difference between Stephens's 'mental maps', and those Central Americans and Mexicans possessed. Stephens surely had adopted the modern cartographic concepts of geographic territories, while in Central America and Mexico lived the old colonial notion of sovereignty based on local jurisdictions. When Stephens and his escort reached the "boundary river" between Guatemala and Mexico:

"No soldiers were visible; all was as desolate as if no human being had ever crossed the boundary before. We had a moment's consultation on which side to encamp, and determined to make a lodgment in Mexico." 46

The crossing of the borderline by Stephens became a fairly subjective experience. When entering the border river to cross the frontier and realizing that the river was deeper than expected, he "wheeled back into Central America". Finally, after managing to cross the river, Stephens wrote, "we all landed safely in Mexico". ${ }^{47}$ Stephens's account of 'crossing boundaries' reveals how strongly the mental maps can determine what a traveler "observes" and "experiences" on his/her voyage. Stephens traveled from country to country, crossing borderlines that existed in his imagination rather than on the road.

The first attempt to start negotiations on boundaries in the early 1830s had ended quickly, and the occupation of Soconusco by Mexico in 1842 spoiled even more the relations between two states. It is only in 1854 when Guatemala and Mexico made an effort to restart discussing their common borderlines. This time the purpose was to first define the limits and then continue with treaties on issues such as commerce and the

45 John L. Stephens, Incidents of Travel in Central America, Chiapas and Yucatan, vol. II (New York: Dover Publications, Inc., 1969, ), p. 228.

${ }^{46}$ Stephens, 243.

${ }^{47}$ Loc. Cit. 
extradition of criminals. ${ }^{48}$ The Mexican representative Juan Nepomuceno de Pereda pointed out the urgency of having an exact knowledge of the frontier that separated the two nations. The ambiguity of the borderlines was considered prejudicial because of contraband commerce and other "intereses nocivos". 49 The negotiations were, however, soon truncated by Guatemalan demand that Mexico pay Chiapas's old debts to Kingdom of Guatemala. ${ }^{50}$ There were no formal contacts around the boundary issue between two countries until 1873, when negotiations began again. Now, even the Guatemalan government expressed firmly that:

"Mientras más clara sea la demarcación de las fronteras entre países limitrofes, habrá menos disputas entre las autoridades fronterizas, y se cortarán de raíz las cuestiones á que da lugar la poca precisión de las líneas divisorias. Por esto es que últimamente se ha adoptado en los países civilizados la práctica de establecer como tales los grados de latitud y longitud."

In other words, the two parts decided finally to behave themselves in a civilized way by establishing their common borders in terms of modern cartography. The borderline was conceived ideally as something perfect that should be determined and asserted on the earth's surface as well as on the map. So, at the moments of disagreement, the negotiating parts could reject an unsatisfying line by calling it "imperfect."

In order to avoid imperfections and ambiguities, the Mexican and Guatemalan governments decided to create a 'scientific' commission to define the boundary on paper and physically on the land. In December 1877, a preliminary agreement was signed about the establishment of a mixed commission, "á efecto de que practique sobre el terreno los reconocimientos científicos, convenientes y porcione á ambos Gobiernos un dato común y exacto, sobre el cual pueden basar sus ulteriores negociaciones." commission was to be composed by twelve astronomic and topographic engineers. In

\footnotetext{
${ }^{48}$ Andrés Dardon, Memoria sobre la cuestión de límites entre Guatemal y México, presentada al señor Ministro de Relaciones Exteriores por el jefe de la Comisión Guatemalteca, 1900 (Guatemala: Centro Editorial "José de Pineda Ibarra" - Ministerio de Educación Pública, 1964), p. 101.

${ }^{49}$ Loc. Cit.

${ }^{50}$ Cuestión de límites. Nota y memorandum, pp. 6 y 48.

${ }^{51}$ Dardon, p. 126.

52 Miguel Martínez, Cuestión entre México y Guatemala. Colección de artículos publicados en la "Voz de México" (México: Imprenta de Ignacio Escalante, 1882)., p. 118.
} 
1882, another agreement was signed and another commission established "para trazar la línea divisoria con la precisión debida en mapas fehacientes, y establecer sobre el terreno monumentos que pongan a la vista los límites de ambas repúblicas... „54

Commissions with changing compositions worked for several years advancing in the demarcation of the boundary line. At the same time, it seems there were attempts by some groups to change the boundary markers, in some places modifying the borderline traced by commissioners. ${ }^{55}$ This fact needs to be studied in order to determine if they were border people disregarded by the commission's work, or government's agents trying to affect the boundary demarcation. The Mexican author César Sepúlveda gives a long list of territorial violations by Guatemalans, while the Guatemalan Andrés Dardon wrote that the inhabitants of Guatemalan frontier were only defending themselves against the attacks of Mexican federal forces in Soconusco. ${ }^{56}$

What, then, were the guidelines for drawing the final borderline? Basically, there were two criteria in the agreement of 1882: in some places 'natural' frontiers such as rivers and mountains were used, and, where nature was not so collaborative, the line was drawn in a "scientific" way following cartographic coordinates of latitude and longitude. The demand of a scientific boundary definition and demarcation derived from the idea that a civilized nation needed to recognize and delimit its territory following the techniques of the modern cartography.

Although initially it was assumed the drawing of lines was to respect people and properties on the borderlands, the final treaty did not include this clause. The Mexican

\footnotetext{
53 Dardon, p. 131.

54 Tratado por el cual los gobiernos de Guatemala y Mexico se ponen de acuerdo sobre el trazado definitivo de la frontera emtre ambos países, México 27 de septiembre de 1882, art. 40.

55 Martínez, p. 123.

56 Sepúlveda mentions that "hubo cruces armados en 1874 y 1875, cuando unos indios guatemaltecos destruyeron la plantación de café de don Matías Romero, situada en territorio mexicano, a la vez que un número de facinerosos destruyó la marca fronteriza..." See, César Sepúlveda, "Historia y problemas de los límites de México: 2.La frontera sur", Historia Mexicana 8(2): 152, 1958. Dardon talks about the invasion of Guatemalan department of San Marcos and the burning of "chozas de los indefensos moradores de Tajumulco" by Mexican troops. According to Dardon, the destruction of boundary markers placed by federal troops was the Indians' legitimate autodefence. See, Dardon, pp. 136-137.
} 
representative José María Lafragua wrote in his draft for the border agreement, "[s]i la línea divisoria atravesare terrenos de propiedad particular, cada fracción de éstos quedará sujeta á las leyes de la nación á que corresponda, segun su situación geográfica. ${ }^{, 57}$ So, when in 1883 the Commission members were planning the procedures for boundary drawing, they talked about the "manera de averiguar qué poblaciones cambiarían de nacionalidad con la nueva línea divisoria". ${ }^{58}$ A line separating people into two different nations had substituted the line that had 'respected communities and properties'.

It is important to take into account that the Mexican representative in boundary negotiations, a coffee plantation owner Matías Romero, possessed a hacienda in Soconusco. Romero had run through different regions of Mexico and Chiapas looking for optimal conditions for successful agroexport production. In 1873, he had established his residence and agricultural business in Soconusco. He also joined forces with another hacendado interested in the issue of limits, the future president of Guatemala Justo Rufino Barrios. These two men became the principal promoters of boundary negotiations. ${ }^{59}$

Generally the goal of the Commission was to indicate "el verdadero punto de la linea"60. And the line was imagined as something continuous, active, something that ran, passed, and crossed rivers and mountains following a perfect path on the earth's uneven surface. Ideally, the line ended up possessing the primary agency in this boundary demarcation endeavor, being the guide for the commission's work. Sometimes it was necessary to clean the road for the line's journey through the abundant forests, by cutting trees and creating a kind of highway for its free movement across the mountains. The imagined line almost magically touched the boundary markers on its path. ${ }^{61}$ Sometimes when the

\footnotetext{
57 José María Lafragua, the Mexican representative, October 9, 1875, in: Martínez, p. 127. See also, Dardon, pp. 159-160.

${ }^{58}$ Dardon, p. 236-237.

${ }^{59}$ García, Resistencia y utopía, p. 159. Se also Emma Cosío Villegas, "El diario de Matías Romero", Historia Mexicana 8(3): 421, enero-marzo 1959. I thank Steven Palmer for reading this paper and agree with his suggestion to study the concepts of private property (political property) in order to explain the transformation of the idea of boundary discussed here. This, however, remains to be studied in the future.

${ }^{60}$ Dardon, 238.

${ }^{61}$ Ibid., 244-247, 320.
} 
drawing was not made "correctly" it was necessary to draw the line again "para que quedara (...) en su posición exacta". To discover the exact location of the line line, it was necessary to use astronomic, or scientific methods. ${ }^{62}$

${ }^{62}$ Ibid., 247, 249. 


\section{CONCLUSION}

As in Cerdanya and Siam, in Guatemala and Mexico, the national boundaries emerged from lasting debates, disputes, and negotiations, during which the terms of dispute- the conceptions of boundary and sovereignty — changed. The notion of frontier zone gave way to the idea of boundary as a line separating two nations. The substitution of the idea of jurisdictional sovereignty by territorial one accompanied the adoption of linear boundary concept. An independent nation needed to define its contours-or, its geobody, as Thongchai Winichakul puts it — in order to become a mature entity and full member of the society of civilized and feasible nations. As it can be observed in the cases discussed above, during the boundary process, the parties' perceptions of what they were negotiating did not always coincide. When Guatemalans still thought it possible to regain the province of Chiapas, they thought in terms of the old colonial jurisdictions. When desiring to consolidate their sovereignty over their southeastern borderlands, Mexicans began talking about boundaries in terms of limits that could be represented by exact lines on maps. Finally, when the question of Chiapas's possession was not at stake any more, both states had adopted the idea of boundary as an exact and continuous line marking nation's territorial sovereignty. Both nations needed to define their contours so that their governments could begin trying to acquire a real control over their respective borderlands. Finally, both countries ended up sharing the terms of discussion, making possible the signing of a boundary treaty between the two nations. 


\section{SOURCES}

\section{Primary}

"Acta por la cual los representantes de los ayuntamientos del partido de Soconusco deciden ser parte de las Provincias Unidas del Centro de América, separándose de Chiapa", in: Vos, Las fronteras de la frontera sur, pp. 146-148.

Dardon, Andrés. Memoria sobre la cuestión de límites entre Guatemala y México, presentada al señor Ministro de Relaciones Exteriores por el jefe de la Comisión Guatemalteca. 1900. Reprinted in Guatemala: Centro Editorial "José de Pineda Ibarra", Ministerio de Educación Pública, 1964.

"Decreto por el cual el presidente Antonio López de Santa-Anna declara agregado irremisiblemente a la República el territorio de Soconusco", México, 11 de septiembre de 1842, in: Vos, Las fronteras de la frontera sur, p. 152.

Gaceta del Gobierno Supremo de Guatemala, April-June 1824.

Guatemala. Reclamación y protesta del Supremo Gobierno del Estado de Guatemala sobre la ocupación de Soconusco, por tropas de la República mexicana, con los documentos en que se fundan. Guatemala: Imprenta de la Paz, 1843.

Larráinzar, Manuel. Chiapas y Soconusco: la cuestión de límites entre México y Guatemala. Chiapas, México: Gobierno del Estado de Chiapas / Consejo National para la cultura y las artes, 1996.

Manning, William R. Diplomatic Correspondence of the United States. Inter-American Affairs, 1831-1860, Vol. III -Central America 1831-1850, Documents 723-995. Washington: Garnegie Enfowment for International Peace, 1933.

Martínez, Miguel. Cuestión entre México y Guatemala. Colección de artículos publicados en la "Voz de México". México: Imprenta de Ignacio Escalante, 1882.

México - Secretaría de Relaciones Exteriores, Cuestión de límites entre México y Guatemala. Nota y memorandum que dirigió el Señor Ministro de Guatemala al Gobierno de México y contestación dada por el Ministro de Relaciones Exteriores de la República. México: Imprenta del Gobierno, en Palacio, á cargo de J.M.Sandoval, 1875.

Stephens, John L. Incidents of Travel in Central America, Chiapas and Yucatan. Vol. II. New York: Dover Publications, 1969.

"Tratado por el cual los gobieros de Guatemala y Mexico se ponen de acuerdo sobre el trazado definitivo de la frontera entre ambos países", Mexico 27 de septiembre de 1882. 
Vázquez, Andrés Clemente. "Bosquejo histórico de la agregacióin a México de Chiapas y Soconusco y de las negociaciones sobre límites entabladas por México con Centro América y Guatemala". Boletín del Archivo Histórico Diplomático Mexicano 36: 1932.

\section{Secondary}

Arriola, Aura Marina. Tapachula, "La perla del Soconusco", ciudad estratégica para la redefinición de las fronteras. Guatemala: FLACSO, 1995.

Benjamin, Thomas. A Rich Land, A Poor People: Politics and Society in Modern Chiapas. Albuquerque: University of New Mexico Press, 1989.

Boggs, S. Whittemore. International Boundaries: A Study of Boundary Functions and Problems (New York: Columbia University Press, 1940).

Carmagnani, Marcelo. "Territorios, provincias y estados: las transformaciones de los espacios políticos en México, 1750-1850”, in: Vázquez, Josefina Zoraida, et al. La fundación del estado mexicano. México: Editorial Patria, 1994.

Cosío Villegas, Emma. "El diario de Matías Romero". Historia Mexicana 8(3): 421, enero-marzo 1959.

Damián, Araceli. “Conformación histórica de la región del Soconusco, Chiapas”, en: Estudios fronterizos: revista del Instituto de Investigaciones Sociales (Universidad Autónoma de Baja California) 7(17): 61-80, set-dic. 1988.

García de León, Antonio. Resistencia y utopia: memorial de agravios y crónica de revueltas y profecías acaecidas en la provincia de Chiapas durante los últimos quinientos años de su historia. Tomos I y II. México: Ediciones Era, 1985.

Granados, Carlos. "La visión mercatoriana del muny las cambiantes relaciones de poder global.” Revista Estudios, Universidad de Costa Rica (12-13, Número especial): 19951996.

Hernández Merida, Arnoldo and María del Rosario Velázquez Gumeta. Chiapas. Síntesis histórica. País de los mayas, tierra del mestizo. Chiapas, México: 1984.

Lockhart, James. The Nahuas After the Conquest: A Social and Cultural History of the Indians of Central Mexico, Sixteenth Through Eighteeth Centuries. Stanford, California: Stanford University Press, 1992.

Nader, Helen. Liberty in Absolutist Spain: The Habsburg Sale of Towns, 1516-1700. Baltimore and London: The John Hopkins University Press, 1990. 
Nobles, Gregory H. "Straight Lines and Stability: Mapping the Political Order of the Anglo-American Frontier", The Journal of American History 80(1): June 1993.

Ortiz Hernández, María de los Angeles. "La oligarquía regional del Soconusco, Chiapas en el siglo XIX”, Ponencia presentada en el Tercer Congreso Centroamericano de Historia, San José, Costa Rica, julio 1996.

Pérez Salas, María Esther and Diana Guillén. Chiapas: una historia compartida. México: Instituto de Investigaciones Dr. José María Luis Mora, 1994.

Sahlins, Peter. "The Nation in the Village: State-Building and Communal Struggles in the Catalan Borderland during the Eighteenth and Nineteenth Centuries". Journal of Modern History 60 (June 1988): 234-263.

. Boundaries: The Making of Frances and Spain in the Pyrenees. Berkeley Los Angeles - London: University of California Press, 1989.

Sepúlveda, César. "Historia y problemas de los límites de México: 2. La frontera sur". Historia Mexicana 8(2): 145-174, 1958.

Sundwall, Gavin A. "Ammianus Geographicus", American Journal of Philology 117(4): 1996.

Vos, Jan de. El sentimiento chiapaneco: ensayo sobre la independencia de Chiapas y su agregación a México. México: Rodrigo Nuñez Editores, 1991.

- Las fronteras de la frontera sur: reseña de los proyectos de expansión que figuraron la frontera entre México y Centroamérica. Villahermosa, Tabasco, México: CIESAS, 1993.

- Vivir en frontera: la experiencia de los indios de Chiapas. México: CIESAS, 1994.

Winichakul, Thongchai. Siam Mapped: A History of the Geo-Body of a Nation. Honolulu: University of Hawai'i Press, 1994. 